ARTICLE

https://doi.org/10.1038/s41467-019-12828-9

\title{
Lake sedimentary biogenic silica from diatoms constitutes a significant global sink for aluminium
}

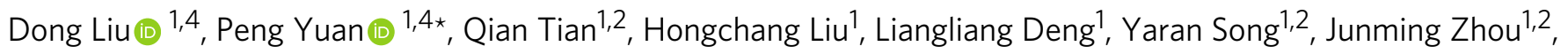
Dusan Losic (10 ${ }^{3}$, Jieyu Zhou ${ }^{1,2}$, Hongzhe Song ${ }^{1,2}$, Haozhe Guo ${ }^{1,2} \&$ Wenxiao Fan ${ }^{1,2}$

Diatoms play an important role in marine biogeochemical cycle of aluminum (AI), as dissolved $\mathrm{Al}$ is taken up by diatoms to build their siliceous frustules and is involved in the sedimentation of diatomaceous biogenic silica (BSi). The Al incorporation in BSi facilitates decreasing the dissolution of marine BSi and thus substantially influences the biochemical processes driven by diatoms, such as $\mathrm{CO}_{2}$ sequestration. However, the role of lake $\mathrm{BSi}$ in the terrestrial biochemical Al cycle has not been explored, though lakes represent the secondlargest sink for BSi. By identifying the previously unexplored high $\mathrm{Al} / \mathrm{Si}$ atomic ratios (up to 0.052) in lake BSi, here we show lake BSi is a large terrestrial Al pool due to its high Al content, and lake sedimentary BSi constitutes a significant global sink for Al, which is on the same magnitude as the Al sink in global oceans.

\footnotetext{
${ }^{1}$ CAS Key Laboratory of Mineralogy and Metallogeny/Guangdong Provincial Key Laboratory of Mineral Physics and Materials, Guangzhou Institute of Geochemistry, Institutions of Earth Science, Chinese Academy of Sciences, 510640 Guangzhou, China. ${ }^{2}$ University of Chinese Academy of Sciences, 100049 Beijing, China. ${ }^{3}$ School of Chemical Engineering, University of Adelaide, Adelaide, SA 5005, Australia. ${ }^{4}$ These authors contributed equally: Dong Liu, Peng Yuan. *email: yuanpeng@gig.ac.cn
} 
luminium $(\mathrm{Al})$ is the third most abundant element in the Earth's crust. Its biogeochemical cycling on land, in water, and in the atmosphere is a central topic of discussion in many geochemical, environmental science, and biological studies ${ }^{1}$ due to the active role of $\mathrm{Al}$ in geochemical processes (e.g., weathering and reverse weathering) as well as the ecological and environmental impacts of $\mathrm{Al}$ (e.g., potential ecotoxicity to organisms $)^{2,3}$. The marine biogeochemical cycling of $\mathrm{Al}$ is strongly associated with the cycling of silicon $(\mathrm{Si})$ through marine diatoms ${ }^{4-10}$. Diatoms account for $\sim 40 \%$ of marine primary production $^{11,12}$, and the gross production of biogenic silica in the ocean reaches $\sim 2.40 \times 10^{14}$ mol year $^{-1}$ (refs. ${ }^{13,14}$ ). Diatoms control the biogenic cycling of Si throughout the world's oceans because they use Si to build siliceous frustules ${ }^{11,15}$. The inorganic part of diatom is diatomaceous biogenic silica (denoted BSi hereafter $)^{16}$. The coupled $\mathrm{Al}$ and Si biogeochemical cycle occurs primarily during $\mathrm{BSi}$ biosynthesis, in which $\mathrm{Al}$ is incorporated into the structure of $\mathrm{BSi}$ with $\mathrm{Al} / \mathrm{Si}$ atomic ratios of up to $\sim 0.008$ (ref. ${ }^{8}$ ). The marine BSi subsequently settles, and $\sim 3 \%$ of the total marine BSi is eventually preserved in the seafloor (with a burial rate of $\left.\sim 6.30 \times 10^{12} \mathrm{~mol}_{\text {year }}{ }^{-1}\right)^{14}$. This process exports organic carbon to the deep sea through the marine biological pump and is therefore important for $\mathrm{CO}_{2}$ sequestration ${ }^{12}$. Furthermore, the process also delivers a large amount of dissolved $\mathrm{Al}$ from marine waters to the seafloor ${ }^{17,18}$. The magnitude of $\mathrm{Al}$ deposition associated with marine $\mathrm{BSi}$ is nearly equivalent to that of the riverine input of dissolved $\mathrm{Al}$ into the oceans ${ }^{17}$, and constitutes an important part of the marine geochemical Al cycle ${ }^{18}$.

While marine $\mathrm{Al}$ cycle in relation to marine $\mathrm{BSi}$ has been well studied $^{19}$, surprisingly, no reports have considered diatomsdriven $\mathrm{Si}$ and $\mathrm{Al}$ co-cycles in lakes, even though lakes represent the second-largest sink of BSi after the oceans and the rate of $\mathrm{BSi}$ burial in global lakes reaches $\sim 1.30 \times 10^{12}$ mol year $^{-1}$ (ref. ${ }^{20}$ ). This rate is on the same order of magnitude as that of marine BSi burial, although the area of lakes $\left(\sim 4.20 \times 10^{6} \mathrm{~km}^{2}\right)$ is significantly smaller than that of oceans $\left(\sim 2.40 \times 10^{9} \mathrm{~km}^{2}\right)$ where BSicontaining sediments occur ${ }^{14,20}$. Moreover, lakes have significantly higher concentrations of dissolved Al than oceans $s^{1,3,21}$. For example, the average $\mathrm{Al}$ concentration of over 400 freshwater lakes (with $\mathrm{pH} \geq 5.0$ ) in USA is higher than $1.0 \mu \mathrm{M}^{3}$. These concentrations are several orders of magnitude greater than those measured in the oceans ${ }^{19,22-26}$; e.g., the dissolved $\mathrm{Al}$ concentrations are $\sim 0.3-5.0 \mathrm{nM}$ in the surface waters of the Pacific Ocean ${ }^{24}$ and rarely exceed $20.0 \mathrm{nM}$ in the surface water of open ocean 19,22,25. Given the high $\mathrm{Al}$ concentration in lakes and the large rate of burial of lake $\mathrm{BSi}$, we hypothesize that the scale of $\mathrm{Al}$ uptake by diatoms and the Al burial due to BSi could differ significantly between lakes and oceans. Quantifying the uptake of dissolved $\mathrm{Al}$ by lake $\mathrm{BSi}$ is therefore crucial to address this question. In particular, identifying the level of $\mathrm{Al}$ incorporation in the structures of lake BSi, which has not been explored previously, is key for estimating the magnitude of $\mathrm{Al}$ burial in relation to $\mathrm{BSi}$ in global lakes, as well as for assessing the role of lake BSi in the terrestrial Al cycle.

Here we show that lake $\mathrm{BSi}$ has high ratios of $\mathrm{Al}$ incorporation in its structure by identifying the level and state of Al incorporation, using a combination of cross-section and surface analysis techniques with high sensitivity, such as focused ion beam (FIB) milling combined with electron microscopy equipped with energy-dispersive X-ray spectroscopy (EDS) and time-of-flight secondary ion mass spectrometry (TOF-SIMS). Our results demonstrate that the proportion of structural Al in lake BSi is high (with $\mathrm{Al} / \mathrm{Si}$ atomic ratio being up to 0.052), which is significantly higher than the maximum $\mathrm{Al} / \mathrm{Si}$ atomic ratio $(\sim 0.008$ $\left(\right.$ ref. $\left.^{8}\right)$ ) of marine BSi. Based on these results, we estimate that the burial rate of $\mathrm{Al}$ through $\mathrm{Al}$ incorporation in $\mathrm{BSi}$ in natural lakes globally is $\sim 1.72 \times 10^{9} \mathrm{~kg}_{\text {year }}-1$, which is on the same order of magnitude as that of the marine Al burial rate $\left(\sim 1.36 \times 10^{9} \mathrm{~kg}\right.$ year $\left.^{-1}\right)$. Therefore, lake BSi is a large terrestrial $\mathrm{Al}$ pool due to the high $\mathrm{Al}$ content in lake $\mathrm{BSi}$, and lake's sedimentary BSi constitutes a significant global sink for $\mathrm{Al}$. This large $\mathrm{Al}$ retention due to lake $\mathrm{BSi}$ needs to be acknowledged in the modelling of the global biogeochemical Al cycle that is currently not considered.

\section{Results}

Identification of Al distribution and coordination in BSi. Two model species of lake diatoms, Cyclotella meneghiniana (Bacillariophyceae: Centricae) (denoted $\mathrm{BSi}-\mathrm{C}$ ) and Nitzschia palea (Pennatae) (BSi-N), which are among the most widely distributed freshwater diatoms in the world ${ }^{27}$, were used for studying the uptake of $\mathrm{Al}$ by lake $\mathrm{BSi}$. The $\mathrm{Si}$ and $\mathrm{Al}$ distributions in the $\mathrm{BSi}$ structures were examined using FIB milling (see Supplementary Fig. 1 for the details of the FIB pretreatment of BSi-C as an example) combined with EDS mapping analysis (Fig. 1). This FIB milling process allows detection of the inner structure of the BSi, thus avoiding possible disturbances from non-structural $\mathrm{Al}$ on the external surface of the BSi. The FIB-EDS mapping images of the BSi-C (Fig. 1c) and BSi-N (Fig. 1f) show that Al is homogeneously distributed in the siliceous structure of lake BSi.

To evaluate the $3 \mathrm{D}$ structural $\mathrm{Al}$ distributions in $\mathrm{BSi}$, TOFSIMS analysis producing $3 \mathrm{D}$ reconstructions of architectural elements was used ${ }^{28}$. The TOF-SIMS analysis result of a frustule
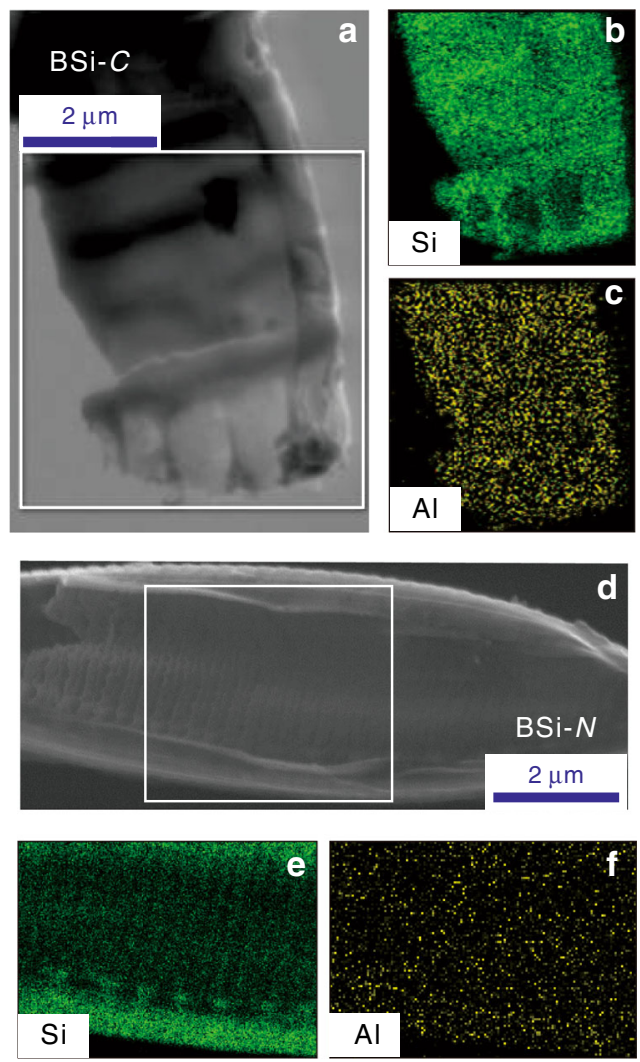

Fig. 1 Morphology and composition of the interior of diatom frustules a Field-emission scanning electron microscope (FESEM) image of the typical morphology of a frustule in BSi-C, pretreated by FIB milling. b Energy-dispersive $\mathrm{X}$-ray spectroscopy (EDS) mapping of Si distribution (green shading) in the frustule of BSi-C. c EDS mapping of Al distribution (yellow shading) in the frustule of BSi-C. d FESEM image of a frustule in BSi$N$, pretreated by FIB milling. e EDS mapping of Si distribution (green shading) in the frustule of BSi-N. $\mathbf{f}$ EDS mapping of Al distribution (yellow shading) in the frustule of BSi-N 

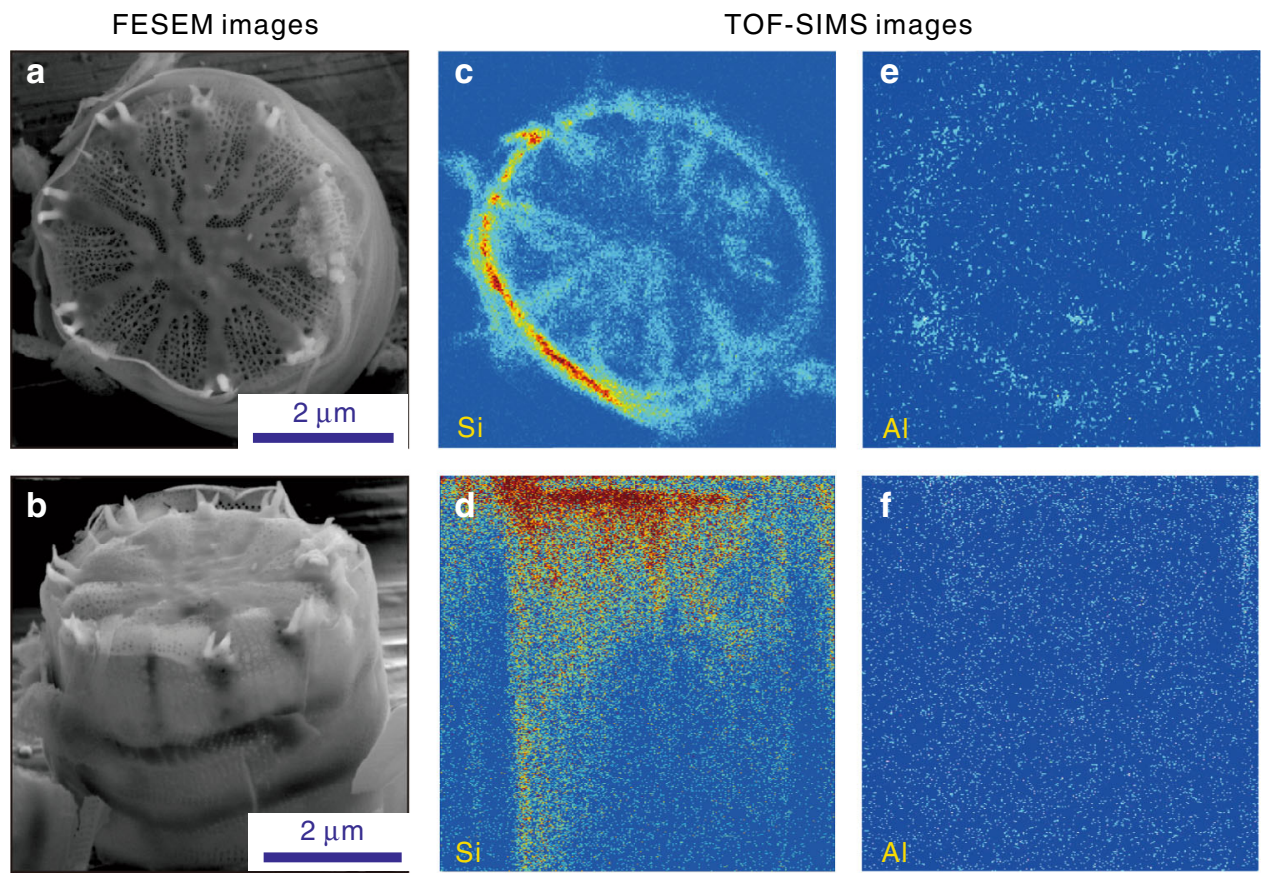

Fig. 2 Morphology and composition of a frustule of BSi-C. a Top view and $\mathbf{b}$ isometric view (tilted $55^{\circ}$ from the top view) of the frustule of BSi-C in the fieldemission scanning electron microscope (FESEM) images. c Top view and $\mathbf{d}$ side view of the three-dimensional (3D) Si distributions obtained by time-offlight secondary ion mass spectrometry (TOF-SIMS). e Top view and $\mathbf{f}$ side view of the 3D Al distributions obtained by TOF-SIMS. The signal fading from left to right in the 3D images in (c) and (d) was caused by the edge effect; i.e., the primary ion beam came from the left side and resulted in unhomogenized signals due to the round shape of the frustule ${ }^{41}$

of $\mathrm{BSi}-\mathrm{C}$ exemplifies the $3 \mathrm{D}$ elemental distribution. A typical disklike C. meneghiniana frustule with a diameter of $\sim 4.0-5.0 \mu \mathrm{m}$ (determined by field-emission scanning electron microscope (FESEM) imaging; Fig. 2a) and a thickness of $\sim 2.5 \mu \mathrm{m}$ (Fig. 2b) was subjected to the $3 \mathrm{D}$ elemental characterization by TOF-SIMS. Figures $2 \mathrm{c}-\mathrm{f}$ show the $\mathrm{Si}$ and $\mathrm{Al}$ distributions in the top view and side view of the frustule of $\mathrm{BSi}-\mathrm{C}$. $\mathrm{Al}$ is clearly homogeneously distributed throughout the structure of the BSi, which is further indicated by the visible 3D Si and $\mathrm{Al}$ distributions from all angles (see Supplementary Movie for a short video of the reconstructed elemental distributions). This result demonstrates the incorporation of $\mathrm{Al}$ into the structure of the BSi of lake diatoms.

Al K-edge X-ray absorption near-edge structure (XANES) spectroscopic analysis was used to reveal the coordination states of the structural Al in the lake BSi. The XANES spectra (Fig. 3) indicate that the $\mathrm{Al}$ in the lake BSi exists mainly in tetrahedral coordination, regardless of the diatom species, as evidenced by the $1566-\mathrm{eV}$ signal of tetrahedral $\mathrm{Al}^{29,30}$. Isomorphous $\mathrm{Si}$ substitution by $\mathrm{Al}$ therefore occurs in natural lake BSi because the $\mathrm{Si}$ in $\mathrm{BSi}$ is tetrahedrally coordinated, verifying the incorporation of $\mathrm{Al}$ into lake $\mathrm{BSi}$ through $\mathrm{Al}-\mathrm{Si}$ substitution. This incorporation mechanism of $\mathrm{Al}$ into $\mathrm{BSi}$ implies that the state of $\mathrm{Al}$ in $\mathrm{BSi}$ is stable because isomorphous substitution is significantly stronger than non-structural incorporation (such as by adsorption), as is well known.

Quantification of structural $\mathrm{Al}$ in BSi and in diatoms. FESEM with EDS spot analysis was used to determine the atomic percentages of $\mathrm{Al}$ and $\mathrm{Si}$ in lake BSi. Over 100 spots from different frustules of lake BSi for each diatom species were collected for the spot analysis. The results reveal high $\mathrm{Al}$ incorporation capacities for all of the lake BSi samples. Based on the atomic percentages of $\mathrm{Al}$ and $\mathrm{Si}$ in the BSi (Fig. 4a, b), the average lake $\mathrm{Al} / \mathrm{Si}$ atomic ratios $\left(\mathrm{Al} / \mathrm{Si}_{\mathrm{BS}}\right)$ are $0.049 \pm 0.003$ and $0.052 \pm 0.003$ for $\mathrm{BSi}-\mathrm{C}$ and
BSi- $N$, respectively (Supplementary Fig. 2) -at least six times greater than the maximum $\mathrm{Al} / \mathrm{Si}_{\mathrm{BSi}}$ ratio $(\sim 0.008)^{8}$ of natural marine $\mathrm{BSi}$. The $\mathrm{Al} / \mathrm{Si}$ ratios of the entire diatoms (i.e., the intact diatoms, in which the organics were not removed) are $0.105 \pm$ 0.008 (C. meneghiniana) and $0.115 \pm 0.012$ (N. palea) (Supplementary Fig. 2). Positive correlations $\left(R^{2} \geq 0.75\right)$ are observed between the Si and Al contents of BSi for the lake BSi samples (Fig. $4 \mathrm{a}, \mathrm{b}$ ), indicating the incorporation of $\mathrm{Al}$ into the $\mathrm{BSi}$ of natural lake diatoms. A similar positive correlation as an indicator of $\mathrm{Fe}$ incorporation into marine $\mathrm{BSi}$ has been clarified previously ${ }^{31}$.

We investigated the influence of the $\mathrm{Al}$ concentration in the culture medium on the $\mathrm{Al} / \mathrm{Si}_{\mathrm{BSi}}$ values of cultured diatoms by $\mathrm{EDS}$ spot analysis. The cultured diatom species are the same as the abovementioned natural lake diatoms. Six Al concentrations (1.0, $2.0,5.0,10.0,50.0$, and $100.0 \mu \mathrm{M})$ were applied, with $\mathrm{Si}$ concentrations remaining constant. The obtained $\mathrm{Al} / \mathrm{Si}_{\mathrm{BSi}}$ values range between 0.045 and 0.055 for cultured C. meneghiniana and between 0.049 and 0.070 for cultured N. palea (grey columns in Fig. 5a, b). In line with the observations for natural lake BSi, the $\mathrm{Al} / \mathrm{Si}_{\mathrm{BSi}}$ values of cultured lake $\mathrm{BSi}$ are also significantly higher than those of the $\mathrm{BSi}$ of cultured marine diatoms $\mathrm{s}^{8,32-34}$, which showed a maximum $\mathrm{Al} / \mathrm{Si}_{\mathrm{BSi}}$ value of only $\sim 0.007$ (for the marine Lauderia annulata diatoms with an $\mathrm{Al}$ concentration of $400 \mathrm{nM}$ in the culture medium $)^{8}$. In addition, similar to those of natural lake diatoms (Supplementary Fig. 2), the $\mathrm{Al} / \mathrm{Si}_{\mathrm{BSi}}$ values of cultured diatoms are lower than the $\mathrm{Al} / \mathrm{Si}$ values of the entire diatoms (Fig. 5). This pattern occurs because $\mathrm{Al}$ exists not only in BSi but also in the organic components of diatoms ${ }^{4}$. This point is supported by the mass spectrometry (MS) data from TOF-SIMS (see Supplementary Fig. 3) analysis of the cultured C. meneghiniana, from which the $\mathrm{Al}$ species associated with the organic components of the Al-bearing lake diatoms were determined. Notably, the specific mechanisms, explaining why diatoms take 


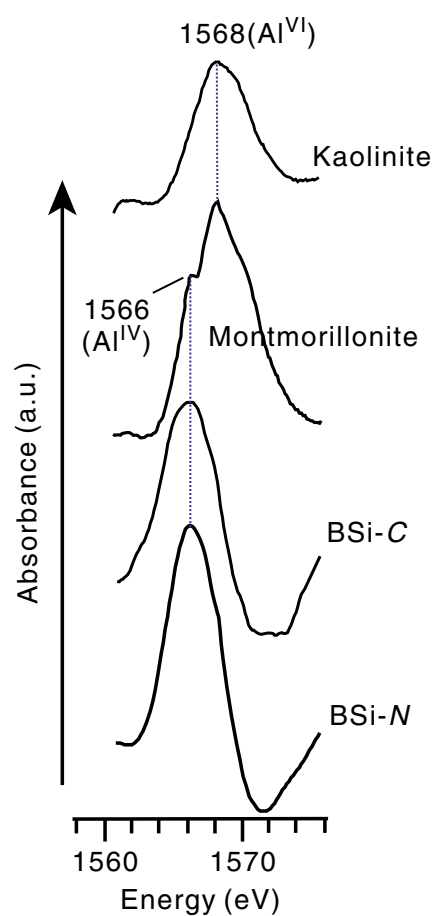

Fig. $3 \mathrm{Al}$ coordination states shown by $\mathrm{X}$-ray absorption spectroscopy. Al K-edge $\mathrm{X}$-ray absorption near-edge structure (XANES) spectra of BSi-C, $B S i-N$, and reference minerals (montmorillonite and kaolinite) were obtained to detect the Al coordination states. Montmorillonite and kaolinite are selected as reference compounds for minerals containing a mix of fourand sixfold coordinated $\mathrm{Al}$ (montmorillonite) and sixfold coordinated $\mathrm{Al}$ only (kaolinite); neither of these minerals is of biogenic origin. The XANES spectrum of kaolinite shows a single energy signal at $1568 \mathrm{eV}$, which is contributed by octahedral $\mathrm{Al}^{29}$. Montmorillonite has a strong signal at 1568 $\mathrm{eV}$ and a weak signal at $1566 \mathrm{eV}$, which corresponds to octahedral and tetrahedral $\mathrm{Al}$, respectively ${ }^{30}$. $\mathrm{Al}^{\mathrm{IV}}$ and $\mathrm{Al}^{\mathrm{VI}}$ represent four- and sixfold coordinated $\mathrm{Al}$, respectively. Source data are provided as a Source Data file

up $\mathrm{Al}$ into their frustules and how $\mathrm{Al}$ is transported or distributed between the inorganic and organic components of diatoms are unknown and have never been explored ${ }^{35}$.

As the $\mathrm{Al}$ concentrations in the culture medium increased from 1.0 to $100.0 \mu \mathrm{M}$, no obvious variation in the obtained $\mathrm{Al} / \mathrm{Si}_{\mathrm{BSi}}$ values for the two types of cultured $\mathrm{BSi}$ is observed. This result suggests that the lowest $\mathrm{Al}$ concentration $(1.0 \mu \mathrm{M})$ may be sufficient to permit the incorporation of $\mathrm{Al}$ into the $\mathrm{BSi}$ of the freshwater diatoms and that high environmental $\mathrm{Al}$ concentrations do not further increase the incorporation of $\mathrm{Al}$ into lake $\mathrm{BSi}$. Furthermore, two Al concentrations $(1.0$ and $2.0 \mu \mathrm{M})$ in the culture medium were selected for comparison. These concentrations are similar to the $\mathrm{Al}$ concentrations in the natural lakes from which C. meneghiniana and N. palea were collected (1.1 and $2.1 \mu \mathrm{M}$, respectively, see Supplementary Table 2). The average Al/ $\mathrm{Si}_{\mathrm{BSi}}$ values of cultured and lake $\mathrm{BSi}$ are similar -0.053 versus 0.049 (C. meneghiniana), respectively; and 0.053 versus 0.052 ( $N$. palea), respectively. Therefore, the cultured lake BSi and natural lake BSi exhibit a similar feature of a high proportion of structural $\mathrm{Al}$, which is not noticeably affected by the environmental $\mathrm{Al}$ concentration or the species of diatom. In addition, FIB-EDS analysis was used to detect $\mathrm{Al}$ incorporation into the internal structure of BSi in the lake sediments. The results show the homogenous $\mathrm{Al}$ distribution in the bulk of BSi of lake sediments (Supplementary Fig. 4), and the average $\mathrm{Al} / \mathrm{Si}_{\mathrm{BSi}}$ values of two frustules of C. meneghiniana and N. palea are $\sim 0.047$ and $\sim 0.051$, respectively.

\section{Discussion}

The small variations in $\mathrm{Al} / \mathrm{Si}_{\mathrm{BSi}}$ values among the $\mathrm{BSi}$ of the lake diatoms cultured with different $\mathrm{Al}$ concentrations suggest that the $\mathrm{Al} / \mathrm{Si}_{\mathrm{BSi}}$ values for lake $\mathrm{BSi}$ are relatively constant at common $\mathrm{Al}$ concentrations (at a level of several micromolars ${ }^{1}$ ) in nonacidified lakes. Furthermore, the $\mathrm{Al} / \mathrm{Si}_{\mathrm{BSi}}$ values of the $\mathrm{BSi}$ from living lake diatoms are similar to those from the lake sediments. This feature is a result of the nature of the isomorphous $\mathrm{Al}-\mathrm{Si}$ substitution in $\mathrm{BSi}$, which guarantees a homogenous $\mathrm{Al}$ distribution and leads to relatively constant $\mathrm{Al} / \mathrm{Si}_{\mathrm{BSi}}$ value, either in local or in bulk of BSi. Therefore, the remarkably high degree of $\mathrm{Al}$ incorporation $\left(\mathrm{Al} / \mathrm{Si}_{\mathrm{BSi}}\right.$ values up to 0.052$)$ in natural lake $\mathrm{BSi}$ substantiates its role as a significant $\mathrm{Al}$ pool in the terrestrial $\mathrm{Al}$ cycle. We adopt the average $\mathrm{Al} / \mathrm{Si}_{\mathrm{BSi}}$ value $(0.049)$ of $\mathrm{BSi}-\mathrm{C}$ as a representative value to estimate the $\mathrm{Al}$ retention due to $\mathrm{BSi}$ in lakes. Notably, such an estimate is conservative because the adopted $\mathrm{Al} / \mathrm{Si}_{\mathrm{BSi}}$ value is situated in the low region of all the $\mathrm{Al} /$ $\mathrm{Si}_{\mathrm{BSi}}$ values determined. Additionally, the $\mathrm{Al}$ sink due to lake $\mathrm{BSi}$ in a certain lake depends on the actual burial rate of BSi, which is influenced by the chemical and ecological conditions of the lake. For lakes globally, the total burial of BSi is $\sim 1.30 \times 10^{12}$ mol year $^{-1}$ (ref. ${ }^{20}$ ). Consequently, the $\mathrm{Al}$ retention due to the burial of $\mathrm{BSi}$ in global lakes is estimated to be $\sim 1.72 \times 10^{9} \mathrm{~kg}_{\text {year }}{ }^{-1}$. By comparison, the burial of $\mathrm{Al}$ in $\mathrm{BSi}$ in the global oceans is $\sim 1.36 \times 10^{9} \mathrm{~kg}$ year $^{-1}$, as estimated from the rate of burial of $\mathrm{Si}$ in the global oceans of $\sim 6.30 \times 10^{12}$ mol year $^{-1}$ (ref. ${ }^{14}$ ) and the highest $\mathrm{Al} / \mathrm{Si}_{\mathrm{BSi}}$ value $(\sim 0.008)^{8}$ in marine BSi. In other words, the magnitude of retention of $\mathrm{Al}$ due to the burial of $\mathrm{BSi}$ in terrestrial lakes globally is comparable to (or even possibly larger than) that in the global oceans.

From the perspective of the biogeochemical Al cycle, the abovementioned Al burial due to lake BSi accounts for $\sim 9.1 \%$ of the total export of terrestrial $\mathrm{Al}$ in biomass to continental sediments $\left(\sim 1.90 \times 10^{10} \mathrm{~kg}_{\text {year }}{ }^{-1}\right)^{36}$. Moreover, the magnitude of this $\mathrm{Al}$ sink is comparable to the magnitude $\left((0.4-2.9) \times 10^{9} \mathrm{~kg}\right.$ year $^{-1}$ (ref. $\left.{ }^{18}\right)$ ) of the input of dissolved $\mathrm{Al}$ into oceans by rivers globally. Based on the burial rate of Al due to BSi $\left(\sim 1.72 \times 10^{9} \mathrm{~kg}\right.$ year $^{-1}$ ) in global lakes and on an estimate that $\sim 5-20 \%$ of total lake BSi is eventually buried in sediments ${ }^{37}$, the total $\mathrm{Al}$ uptake by the BSi of global lakes is on the order of $(\sim 0.86-3.44) \times 10^{10} \mathrm{~kg}$ year $^{-1}$. Therefore, the $\mathrm{Al}$ occurrence in lake BSi, either in the waters or in the sediment, constitutes an important part of the global Al cycle.

The large $\mathrm{Al}$ pool due to $\mathrm{Al}$ incorporation in lake $\mathrm{BSi}$, especially the Al sink through the burial of lake BSi, has not been considered in the scientific literature, but may have substantial effects on the global Al cycle. The scale of the terrestrial dissolved $\mathrm{Al}$ exported to oceans could be affected by the magnitude of $\mathrm{Al}$ burial in lakes, thereby mediating related marine geochemical processes, such as reverse weathering in which $\mathrm{Al}$ ions are active reactants ${ }^{2}$. For modelling and interpretations of the global $\mathrm{Al}$ cycle, the $\mathrm{Al}$ uptake by lake BSi and its potential consequences must be taken into account.

$\mathrm{Al}$ incorporation into amorphous silica has long been known to be able to reduce silica solubility ${ }^{5,7-9,38}$. The decrease in solubility of the BSi of cultured marine diatoms with $\mathrm{Al}$ incorporation was also confirmed ${ }^{8}$. The mechanism of the abovementioned dissolution-inhibition effect has been ascribed to the production of negative charges by $\mathrm{Al}$ incorporation in silica, which repels $\mathrm{OH}^{-}$and thereby retards the dissolution of silica ${ }^{7-9,38}$. The $\mathrm{Al} /$ $\mathrm{Si}_{\mathrm{BSi}}$ values of the $\mathrm{BSi}$ of marine diatoms normally remain at a level of $10^{-4}-10^{-3}$ in marine waters with generally low $\mathrm{Al}$ concentrations $^{33}$. The low extent of $\mathrm{Al}$ incorporation in marine BSi is thought to be unable to obviously affect the dissolution kinetics or the solubility of marine $\mathrm{BSi}^{6,9}$. In contrast, the noticeable $\mathrm{Al}$ incorporation in lake BSi substantially decreases its solubility. 

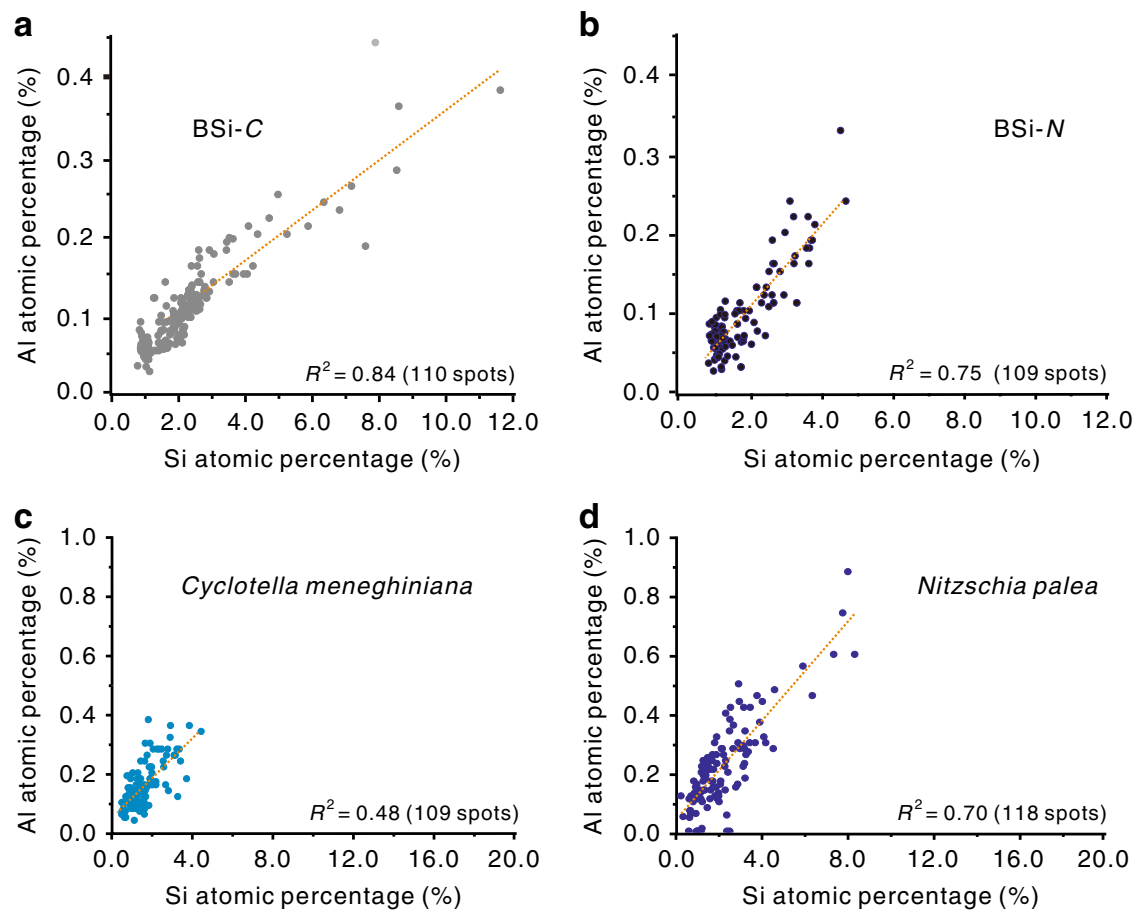

Fig. $4 \mathrm{Al}$ and $\mathrm{Si}$ atomic percentages in frustules and entire diatoms. a The data of $\mathrm{Al}$ and $\mathrm{Si}$ atomic percentages for $\mathrm{BSi}-\mathrm{C} ; \mathbf{b}$ the data for $\mathrm{BSi}-\mathrm{N} ; \mathbf{c}$ the data for the entire Cyclotella meneghiniana diatoms; and $\mathbf{d}$ the data for the entire Nitzschia palea diatoms. Energy-dispersive X-ray spectroscopy (EDS) spot analysis was used for the determination, and the data of more than 100 spots (specified in the brackets of a-d) from over 35 entire diatoms or their BSi were collected. $R^{2}$ is the correlation coefficient between the atomic percentages of Al and Si (the linear fitting formulas are given in Supplementary Table 1). Source data are provided as a Source Data file

a

Entire diatom

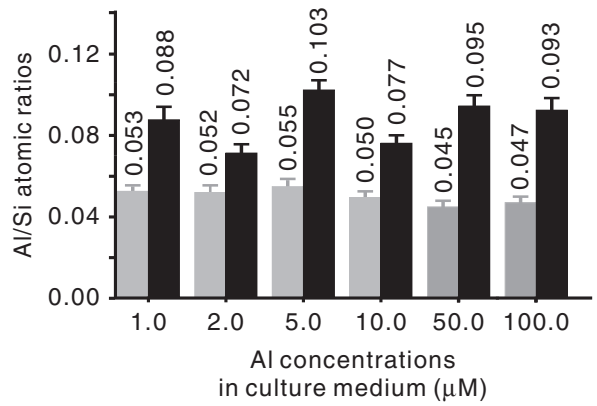

b $\begin{array}{lc}\text { BSi } & \text { Nitzschia palea } \\ \text { Entire diatom } & \text { (cultured diatom) }\end{array}$

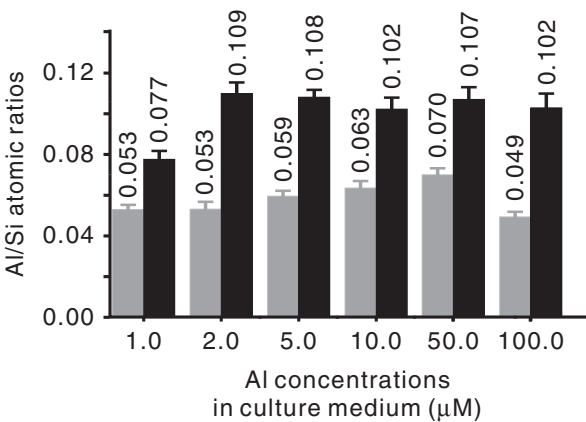

Fig. $5 \mathrm{Al} / \mathrm{Si}$ atomic ratios of cultured diatoms and their frustules. a The average Al/Si atomic ratios of the entire Cyclotella meneghiniana diatoms (black columns) cultured in media with various Al concentrations and of their biogenic silica (BSi) (grey columns). b The data of the entire Nitzschia palea diatoms (black columns) and of their BSi (grey columns). The energy-dispersive X-ray spectroscopy (EDS) spot analysis for the determination of Al/Si atomic ratios is based on over 100 spots for each sample. Error bounds were obtained on the basis of $95 \%$ confidence interval for the analysis on Al/Si atomic ratios. Source data are provided as a Source Data file

In a 10-day dissolution test aiming at examining the dissolution-inhibition effect of Al-bearing lake BSi, the Al-scarce BSi showed high dissolution extent, $90.2 \%$ (wt\%) for the BSi from the cultured C. meneghiniana and $79.6 \%$ for that from the cultured N. palea (details in Supplementary Fig. 5). However, the 10day dissolution extents of the Al-bearing $\mathrm{BSi}$ with different $\mathrm{Al} /$ $\mathrm{Si}_{\mathrm{BSi}}$ values decreased to $49.6-67.7 \%$ and $55.4-66.6 \%$ (Supplementary Fig. 5), for the cultured C. meneghiniana and N. palea, respectively.

The consequences of such a distinct dissolution-inhibition effect of lake BSi deserve to be considered in the preservation of lake BSi. The annual burial rate of lake BSi normalized to the total area of global lakes is $18.2 \mathrm{~g} \mathrm{~m}^{-2}$ year $^{-1}$ (ref. ${ }^{20}$ ). This value is $\sim 11.5$ times greater than that of marine BSi $\left(1.58 \mathrm{~g} \mathrm{~m}^{-2}\right.$ year $\left.^{-1}\right)$ normalized to the area $\left(\sim 2.40 \times 10^{9} \mathrm{~km}^{2}\right)$ of BSi-containing oceanic regions ${ }^{14}$. Given the key role of diatoms in the closely coupled Si and C cycles through the biological pump ${ }^{12}$, this result suggests that the biological pump driven by diatoms in lakes is more efficient than its counterpart in oceans, making the former biological pump more conducive to $\mathrm{CO}_{2}$ sequestration. The pronounced dissolution-inhibition effect likely contributes to the high efficiency of sedimentation and preservation of lake BSi, although quantifying this contribution is difficult at the present stage due to the lack of data of other variables, such as the scale of biological scavenging ${ }^{6}$. The role of lake BSi for carbon sequestration over geological history or during the present, and the 
potential impacts by the preservation of lake BSi on mediating global climate change, warrants further study.

\section{Methods}

Lake diatoms. Two species of diatom, C. meneghiniana (Bacillariophyceae: Centricae) and N. palea (Pennatae), were collected from Wuliangsuhai Lake and Taihu Lake in China, respectively. These samples are referred to as natural lake diatoms. Site descriptions and sampling procedures are provided in the Supplementary Materials (Supplementary Figs. 6 and 7 and the associated text). A plankton net with a $0.22-\mu \mathrm{m}$ mesh was used to collect the living diatoms of C. meneghiniana, and a Teflon collector was used for $N$. palea. The living diatoms were picked from the collected specimens using an Olympus Microscope (CX31) at 1000× magnification. The identification of the species of the living diatoms was achieved by determining the rbcL gene sequences of the diatoms ${ }^{39}$ (Supplementary Fig. 8). Before the analysis such as determination of $\mathrm{Al} / \mathrm{Si}$ atomic ratios through $\mathrm{EDS}$ analysis, diatom samples were cleaned in $0.1 \mathrm{~N}$ citric acid for $72 \mathrm{~h}$ and rinsed three times with deionized water, and the products were subjected to centrifugation and subsequent freeze-drying.

Cultivation of diatoms. Cultured diatoms of the same two species as the abovementioned living diatoms were provided by the Freshwater Algae Culture Collection at the Institute of Hydrobiology (FACHB), Chinese Academy of Sciences. After successive culturing and harvesting over many generations in an $\mathrm{Al}$-free medium, these diatoms contain very little $\mathrm{Al}(\mathrm{Al} / \mathrm{Si}$ atomic ratios $<0.001)$. These Al-scarce diatoms were used as control samples for comparison. The diatoms were grown in the culture medium (details of the components are given in Supplementary Table 3) at a temperature of $25^{\circ} \mathrm{C}$ under a $12 / 12$ light/dark cycle at an intensity of $71 \mu \mathrm{mol}$ photons $\mathrm{m}^{-2} \mathrm{~s}^{-1}$ for $480 \mathrm{~h}$ (one diatom life cycle). The $\mathrm{pH}$ of the diatom culture medium was adjusted to 8.0 using a solution of $\mathrm{NaOH}$. This $\mathrm{pH}$ is close to the $\mathrm{pH}$ of the abovementioned lakes where the natural lake diatoms were collected. The $\mathrm{pH}$ of the culture medium during culture process is in the range of 8.0-8.4. Al-bearing diatoms were obtained by adding $\mathrm{AlCl}_{3}$ to the diatom medium to reach designated $\mathrm{Al}$ concentrations of $1.0,2.0,5.0,10.0,50.0$, and $100.0 \mu \mathrm{M}$. The diatoms cultured in the abovementioned weakly alkaline condition of this work have a high level of Al tolerance, unlike the pronounced ecotoxicity of $\mathrm{Al}$ to organisms shown at the acidic or circumneutral conditions ${ }^{40}$. The growth inhibition of the diatom cells in the presence of $\mathrm{Al}$ was found to be minor, even for the high $\mathrm{Al}$ concentrations of 50.0 and $100.0 \mu \mathrm{M}$ (Supplementary Fig. 9). The cultured diatoms were treated according to the same procedures described above before further analysis, such as microscopic characterization.

Extraction of BSi. Two chemical treatments were used to obtain the BSi samples from the natural lake diatoms and the cultured diatoms, including immersion in a $30 \%$ hydrogen peroxide solution for $72 \mathrm{~h}$ to remove the organic matrix of the diatoms, and then washing in $0.1 \mathrm{~N}$ acetic acid for $72 \mathrm{~h}$ to remove non-structural $\mathrm{Al}^{4}$. These steps were repeated until complete removal of the organic components was achieved. To confirm the removal of organics, carbon elemental analysis on the BSi was performed using a Vario EL III elemental analyzer, in which samples were oxidized in a combustion tube in the presence of oxygen at high temperature $\left(\geq 1150^{\circ} \mathrm{C}\right)$. Samples of $\sim 2.00 \mathrm{mg}$ were placed in tin boats with a size of $6 \times 12 \mathrm{~mm}$. The carbon contents of the BSi extracted from the diatoms were all below the detection limit $(<40 \mathrm{ppm})$.

Determination of $\mathbf{A l} / \mathbf{S i}$ atomic ratios. The $\mathrm{Al} / \mathrm{Si}$ atomic ratios in the natural lake diatoms and the cultured diatoms and their BSi were determined by an EDS method using a Hitachi SU8010 FESEM attached to an AMETEK energy dispersive $\mathrm{X}$-ray spectrometer. The samples for SEM characterization were pre-treated by carbon coating. Over 100 spots from more than 35 entire diatoms and their BSi of each diatom species were detected using FESEM-EDS spot analysis with a voltage of $15 \mathrm{kV}$ and a current of $20 \mu \mathrm{A}$. For the cultured diatoms and their BSi, 103 spots of EDS spot analysis for each sample were collected.

FIB-EDS mapping analysis. FIB-EDS mapping analyses of the natural lake BSi were carried out to reveal the $\mathrm{Al}$ and $\mathrm{Si}$ distributions in the BSi samples. This process was achieved using a FIB-SEM (GAIA3, Tescan) equipped with a Triglav FESEM column, a Cobra FIB column, a multichannel gas injection system, and an Oxford Instrument X-Max 80 Aztec energy-dispersive X-ray spectrometer. A single frustule of BSi selected for characterization was picked using a nanomanipulator (Oxford OmniProbe 400), and the sample surface was milled using a focused gallium ion $\left(\mathrm{Ga}^{+}\right)$beam with an accelerating voltage of $30 \mathrm{kV}$, a current of $1.0 \mathrm{nA}$, and a total milling time of $1 \mathrm{~min}$.

TOF-SIMS analysis. A frustule of C. meneghiniana $\mathrm{BSi}(\mathrm{BSi}-\mathrm{C})$ was analysed by TOF-SIMS to identify the 3D elemental distribution of $\mathrm{Al}$ and $\mathrm{Si}$ in the BSi. The SIMS instrument is equipped with a reflection-type TOF analyser (GAIA TOF-SIMS, Tescan); a liquid metal ion gun with $30 \mathrm{keV}$ of $\mathrm{Ga}^{+}$, an ion beam current of $25 \mathrm{pA}$, and an angle of incidence to the normal of $55^{\circ}$ for bombarding the surface; and an electron beam for imaging. Each layer of $\mathrm{BSi}-\mathrm{C}$ is produced with an ion beam for surface analysis, and a sputtering ion beam is used to ablate the surface layer ${ }^{28}$.

Al K-edge XANES analysis. Al K-edge XANES analysis was performed on the BL08U beamline of the Shanghai Synchrotron Radiation Facility (SSRF; Shanghai, China). A dispersion was prepared by mixing BSi with ultrapure water and subsequently shaking the mixture to disperse the samples. The dispersion was dropped onto tinfoil and smeared evenly. After the dispersion was air-dried, the tinfoil coated with BSi was positioned at a $90^{\circ}$ angle to the incident X-ray beam. Al K-edge XANES spectra were recorded in total electron yield mode in a vacuum chamber $\left(<10^{-5}\right.$ torr, $\left.25^{\circ} \mathrm{C}\right)$ from $1558 \mathrm{eV}$ to $1576 \mathrm{eV}$ across the $\mathrm{Al} \mathrm{K}$-edge with a step of $0.1 \mathrm{eV}$ and a dwell time of $2 \mathrm{~s}$, and the measurement was repeated three times at each energy level. The XANES spectra were then normalized with the IFEFFIT program.

Dissolution experiment of Al-bearing BSi. To determine the effect of $\mathrm{Al}$ incorporation on the solubility of BSi, the BSi samples extracted from the cultured $C$. meneghiniana and N. palea were used. A series of BSi samples with average $\mathrm{Al} / \mathrm{Si}$ atomic ratios ranging from $<0.001$ (Al-scarce $\mathrm{BSi}$ ) to $0.045-0.070$ (Al-bearing $\mathrm{BSi}$ ) were used for the dissolution experiment; $0.50 \mathrm{mg}$ of BSi sample was dissolved in $100 \mathrm{~mL}$ of deionized water in a Teflon beaker at $25^{\circ} \mathrm{C}$. After 10 days of dissolution, the resulting solution was centrifuged and $1.0 \mathrm{~mL}$ of solution from the supernatant was collected for the determination of $\mathrm{Si}$ concentration, which was performed using a Thermo Scientific iCAP 7000 inductively coupled plasma atomic emission spectrometer (ICP-AES). Before ICP-AES analysis, $1.0 \mathrm{~mL}$ of $2.0 \% \mathrm{HNO}_{3}$ was added into the solution and the resultant extract solution was left overnight. The parameters of ICP-AES were as follows: a power of $1150 \mathrm{~W}$, a plasma flow rate of $12 \mathrm{~L} \mathrm{~min}^{-1}$, a coating gas flow rate of $0.5 \mathrm{~L} \mathrm{~min}^{-1}$, and a nebulisator pressure of $200 \mathrm{kPa}$. Digestions of the blank sample were simultaneously carried out for calibration. The 10-day dissolution extent of BSi was calculated using the following equation:

$$
D(\%)=\frac{\frac{\frac{M \times 2.0 \times 10^{-3}}{2.1 \times 10^{-3}} \times 60.1 \times 10^{-3}}{1.0 \times 10^{-3}} \times 100 \times 10^{-3}}{0.5} \times 100
$$

where $D(\%)$ is the 10-day dissolution extent of $\mathrm{BSi}, M\left(\mathrm{mg} \mathrm{L}^{-1}\right)$ is the concentration of Si detected by ICP-AES, and the atomic weights of $\mathrm{Si}$ and $\mathrm{SiO}_{2}$ are 28.1 and $60.1 \mathrm{~g} \mathrm{~mol}^{-1}$, respectively.

Reporting Summary. Further information on research design is available in the Nature Research Reporting Summary linked to this article.

\section{Data availability}

The authors declare that the main data supporting the findings of this study are available within the article and its Supplementary Information files. Extra data are available from the corresponding author upon request. The source data underlying Figs. 3, 4, and 5 and Supplementary Figs. 2, 3, 5, and 9 are provided as a Source Data file.

Received: 17 December 2018; Accepted: 3 October 2019; Published online: 23 October 2019

\section{References}

1. Driscoll, C. T. \& Postek K. M. The chemistry of aluminum in surface waters. in The Environmental Chemistry of Aluminum 2nd edn (ed Sposito, G.) Ch. 9, 364-366 (CRC Press, Boca Raton, 1995).

2. Isson, T. T. \& Planavsky, N. J. Reverse weathering as a long-term stabilizer of marine $\mathrm{pH}$ and planetary climate. Nature 560, 471 (2018).

3. Driscoll, C. T. \& Schecher, W. D. The chemistry of aluminum in the environment. Environ. Geochem. Health 12, 28-49 (1990).

4. Moran, S. B. \& Moore, R. M. Evidence from mesocosm studies for biological removal of dissolved aluminium from sea water. Nature 335, 706-708 (1988).

5. Van Cappellen, P., Dixit, S. \& van Beusekom, J. Biogenic silica dissolution in the oceans: Reconciling experimental and field-based dissolution rates. Global Biogeochem. Cycles 16, 23-1-23-10 (2002).

6. Loucaides, S., Cappellen, P. V., Roubeix, V., Moriceau, B. \& Ragueneau, O. Controls on the recycling and preservation of biogenic silica from biomineralization to burial. Silicon 4, 7-22 (2012).

7. Van Bennekom, A. J., Fred Jansen, J. H., van der Gaast, S. J., Van Iperen, J. M. \& Pieters, J. Aluminium-rich opal: an intermediate in the preservation of biogenic silica in the Zaire (Congo) deep-sea fan. Deep Sea Res. A 36, 173-190 (1989)

8. Gehlen, M. et al. Unraveling the atomic structure of biogenic silica: evidence of the structural association of $\mathrm{Al}$ and $\mathrm{Si}$ in diatom frustules. Geochim. Cosmochim. Acta 66, 1601-1609 (2002). 
9. Dixit, S., Van Cappellen, P. \& van Bennekom, A. J. Processes controlling solubility of biogenic silica and pore water build-up of silicic acid in marine sediments. Mar. Chem. 73, 333-352 (2001).

10. Boyd, P. W., Ellwood, M. J., Tagliabue, A. \& Twining, B. S. Biotic and abiotic retention, recycling and remineralization of metals in the ocean. Nat. Geosci. 10, 167-173 (2017).

11. Armbrust, E. V. The life of diatoms in the world's oceans. Nature 459, 185-192 (2009).

12. Tréguer, $\mathrm{P}$. et al. Influence of diatom diversity on the ocean biological carbon pump. Nat. Geosci. 11, 27-37 (2018).

13. Conley, D. J. \& Carey, J. C. Silica cycling over geologic time. Nat. Geosci. 8, 431-432 (2015).

14. Tréguer, P. J. \& De La Rocha, C. L. The world ocean silica cycle. Annu. Rev. Mar. Sci. 5, 477-501 (2013).

15. Kröger, N., Deutzmann, R. \& Sumper, M. Polycationic peptides from diatom biosilica that direct silica nanosphere formation. Science 286, 1129-1132 (1999).

16. Parker, A. R. \& Townley, H. E. Biomimetics of photonic nanostructures. Nat. Nanotechnol. 2, 347-353 (2007).

17. Mackenzie, F. T., Stoffyn, M. \& Wollast, R. Aluminum in seawater: control by biological activity. Science 199, 680-682 (1978).

18. Stoffyn, M. \& Mackenzie, F. T. Fate of dissolved aluminum in the oceans. Mar. Chem. 11, 105-127 (1982).

19. Gehlen, M., Heinze, C., Maier-Reimer, E. \& Measures, C. I. Coupled Al-Si geochemistry in an ocean general circulation model: a tool for the validation of oceanic dust deposition fields? Global Biogeochem. Cycles 17, 28-21 (2003).

20. Frings, P. J. et al. Lack of steady-state in the global biogeochemical Si cycle: emerging evidence from lake Si sequestration. Biogeochemistry 117, 255-277 (2014).

21. Schindler, D. W. et al. Long-term ecosystem stress: the effects of years of experimental acidification on a small lake. Science 228, 1395-1401 (1985).

22. Hydes, D. J. Aluminum in seawater: control by inorganic processes. Science 205, 1260-1262 (1979).

23. Orians, K. J. \& Bruland, K. W. The biogeochemistry of aluminum in the Pacific Ocean. Earth Planet. Sci. Lett. 78, 397-410 (1986).

24. Orians, K. J. \& Bruland, K. W. Dissolved aluminium in the central North Pacific. Nature 316, 427-429 (1985).

25. Middag, R., van Slooten, C., de Baar, H. J. W. \& Laan, P. Dissolved aluminium in the Southern Ocean. Deep Sea Res. Part II Top. Stud. Oceanogr. 58, 2647-2660 (2011).

26. Hydes, D. J., Lange, G. J. D. \& Baar, H. J. W. D. Dissolved aluminium in the Mediterranean. Geochim. Cosmochim. Acta 52, 2107-2114 (1988).

27. Finlay, B. J., Monaghan, E. B. \& Maberly, S. C. Hypothesis: The rate and scale of dispersal of freshwater diatom species is a function of their global abundance. Protist 153, 261-273 (2002).

28. Jung, S., Foston, M., Kalluri, U. C., Tuskan, G. A. \& Ragauskas, A. J. 3D chemical image using TOF-SIMS revealing the biopolymer component spatial and lateral distributions in biomass. Angew. Chem. Int. Ed. Engl. 51, 12005-12008 (2012).

29. Li, D. E., Bancroft, G. M., Fleet, M. E., Feng, X. H. \& Pan, Y. M. Al K-Edge XANES spectra of aluminosilicate minerals. Am. Mineral. 80, 432-440 (1995).

30. Ildefonse, P. et al. Aluminium X-ray absorption near edge structure in model compounds and Earth's surface minerals. Phys. Chem. Miner. 25, 112-121 (1998).

31. Ingall, E. D. et al. Role of biogenic silica in the removal of iron from the Antarctic seas. Nat. Commun. 4, 1-6 (2013).

32. Van Hulten, M. M. P. et al. On the effects of circulation, sediment resuspension and biological incorporation by diatoms in an ocean model of aluminium. Biogeosciences 11, 3757-3779 (2014).

33. Vrieling, E. G., Poort, L., Beelen, T. P. M. \& Gieskes, W. W. C. Growth and silica content of the diatoms Thalassiosira weissflogii and Navicula salinarum at different salinities and enrichments with aluminium. Eur. J. Phycol. 34, 307-316 (1999).

34. Koning, E., Gehlen, M., Flank, A. M., Calas, G. \& Epping, E. Rapid postmortem incorporation of aluminum in diatom frustules: evidence from chemical and structural analyses. Mar. Chem. 106, 208-222 (2007).

35. Zhou, L., Tan, Y., Huang, L., Fortin, C. \& Campbell, P. G. C. Aluminum effects on marine phytoplankton: implications for a revised iron hypothesis (Iron-Aluminum Hypothesis). Biogeochemistry 139, 123-137 (2018).

36. Rauch, J. N. \& Pacyna, J. M. Earth's global Ag, Al, Cr, Cu, Fe, Ni, Pb, and $\mathrm{Zn}$ cycles. Global Biogeochem. Cycles 23, GB2001 1-16 (2009).
37. Leng, M. J. \& Barker, P. A. A review of the oxygen isotope composition of lacustrine diatom silica for palaeoclimate reconstruction. Earth Sci. Rev. 75, 5-27 (2006).

38. Iler, R. K. The occurrence, dissolution, and deposition of silica. in The Chemistry of Silica Solubility: Polymerization Colloid and Surface Properties and Biochemistry. (ed Iler, R. K.) Ch. 1, 40-58 (John Wiley \& Sons Inc., Press, New York, 1979).

39. Couradeau, E. et al. An early-branching microbialite cyanobacterium forms intracellular carbonates. Science 336, 459-462 (2012).

40. Gensemer, R. W. \& Playle, R. C. The bioavailability and toxicity of aluminum in aquatic environments. Crit. Rev. Environ. Sci. Technol. 29, 315-450 (1999).

41. Vering, G., Crone, C., Bijma, J. \& Arlinghaus, H. F. TOF-SIMS characterization of planktonic foraminifera. Appl. Surf. Sci. 203-204, 785-788 (2003).

\section{Acknowledgements}

We thank Dr. Changwei Lv (Inner Mongolia University) for the advice of the sampling of lake diatoms from Wuliangsu Lake, Dr. Lijuan Zhang (SSRF) for the analysis of XANES, and Dr. Huisheng Jiao and Fang Zhang (Tescan China) for the analyses of TOF-SIMS and FIB. The financial supports from the National Natural Scientific Foundation of China (Grant Nos. 41202024, 40872042, and 41772041), Natural Science Foundation for Distinguished Young Scientists of Guangdong Province (Grant No. 2016A030306034), National Special Support for High-Level Personnel and Youth Innovation Promotion Association CAS for the excellent members (2016-81-01), Science and Technology Planning Project of Guangdong Province, China (2017B020237003), and the Open Funds of SSRF (2016-SSRF-PT-005390/005176). This is a contribution (No. IS-2757) from GIGCAS

\section{Author contributions}

D.Li. and P.Y. designed the experiments and wrote the manuscript. Q.T., H.G., and W.F collected the samples of lake diatoms. Q.T., Y.S., and J.Y.Z. carried out the culture of diatoms and EDS analysis. H.L. and Q.T. performed the XANES analysis. D.Lo. was involved in the discussion on the data analysis and revision of the draft. L.D., J.M.Z., J.Y.Z., H.S., and W.F. pretreated the lake or cultured diatoms and were involved in the TOFSIMS and FIB analysis.

\section{Competing interests}

The authors declare no competing interests.

\section{Additional information}

Supplementary information is avaliable for this paper at https://doi.org/10.1038/s41467019-12828-9.

Correspondence and requests for materials should be addressed to P.Y.

Peer review information Nature Communications thanks the anonymous reviewers for their contributions to the peer review of this work.

Reprints and permission information is available at http://www.nature.com/reprints

Publisher's note Springer Nature remains neutral with regard to jurisdictional claims in published maps and institutional affiliations.

Open Access This article is licensed under a Creative Commons Attribution 4.0 International License, which permits use, sharing, adaptation, distribution and reproduction in any medium or format, as long as you give appropriate credit to the original author(s) and the source, provide a link to the Creative Commons license, and indicate if changes were made. The images or other third party material in this article are included in the article's Creative Commons license, unless indicated otherwise in a credit line to the material. If material is not included in the article's Creative Commons license and your intended use is not permitted by statutory regulation or exceeds the permitted use, you will need to obtain permission directly from the copyright holder. To view a copy of this license, visit http://creativecommons.org/ licenses/by/4.0/.

(C) The Author(s) 2019 